\title{
Phytoremediation of Lead and Chromium using Sunflower (Helianthus annuus L.) in Contaminated Soils of IBB University, Lapai, Nigeria
}

\section{*11ABDULLAHI, MB; ${ }^{2}$ ANIMASHAUN, IM; ${ }^{1}$ GARBA, Y; ${ }^{1}$ ADAMU, A; ${ }^{1}$ YISA, PB}

\author{
${ }^{*}$ Department of Crop Production, Ibrahim Badamasi Babangida University, Lapai, Nigeria \\ ${ }^{2}$ Department of Agriculture and Bioresources Engineering, Federal University of Technology, Minna, Nigeria \\ *Corresponding Author Email: ambello84@yahoo.com, Tel: 07030477918
}

\begin{abstract}
Heavy metals are known to have adverse effect on ecosystem and human health when ingested beyond tolerant limit as such phytoremediation utilizes plants to remediate metal polluted areas. The objectives of this study is to evaluate the potentials of sunflower in phytoremediation of chromium and lead from contaminated soil and to examine the rate of accumulation in roots, stems and leaves of sunflower (Helianthus annuus L.). Results showed that the plant has high concentration of $\mathrm{Pb}(1.77 \mathrm{mg} / \mathrm{kg}$ ) at 10 and 12 (WAP) and there was no significant difference in the absorption rate throughout the experimental period, while at 2 WAP low concentration of $\mathrm{Pb}(1.52 \mathrm{mg} / \mathrm{kg})$ was observed. The accumulation rate in the plant parts shows significant difference $(\mathrm{p}<0.05)$ at 2 and 6 WAP. The roots recorded the highest accumulation rate of both $\mathrm{Pb}$ and $\mathrm{Cr} 2.04 \mathrm{mg} / \mathrm{kg}$ and $1.60 \mathrm{mg} / \mathrm{kg}$ respectively, while the leaves recorded the least values $1.12 \mathrm{mg} / \mathrm{kg}$ and $0.09 \mathrm{mg} / \mathrm{kg}$ of $\mathrm{Pb}$ and $\mathrm{Cr}$ respectively. From results obtained heavy metal accumulation in sunflower was observed to be in the form leaves<stems<roots. Finally, sunflower has demonstrated to be a good absorber of $\mathrm{Pb}$ and $\mathrm{Cr}$. Hence, it can be used in the phytoremediation of heavy metal contaminated soils.
\end{abstract}

DOI: https://dx.doi.org/10.4314/jasem.v25i6.18

Copyright: Copyright (C) 2021 Abdullahi et al. This is an open access article distributed under the Creative Commons Attribution License (CCL), which permits unrestricted use, distribution, and reproduction in any medium, provided the original work is properly cited.

Dates: Received: 20 March 2021; Revised: 27 April 2021; Accepted: 07 May 2021

Keywords: Chromium, Lead, Leaves, Roots, Stems, Sunflower

Prevalence of heavy metal from one place to another depends upon the source of individual pollutant Adejube et al., (2017). High concentration of heavy metals in the soil brings about changes in the content of the macronutrient in plants grown under lead stress Kamil et al., (2019). Heavy metal accumulation may occur once penetrated into the root system or may be translocated aerially to other parts of the plant Shahid et al., (2011). Large amount of lead and chromium uptake was accumulated in the roots, followed by the stems and leaves. Poisonous pollutant causes series of lamella set up in the seed germination, chloroplast, chlorosis, number of mitochondrial cristae, reduces the process of photosynthesis and cell division Winska-Krysiak et al., (2015), crop tolerance index (TI) of sunflower (Atta et al., 2014), decrease total protein content, gene expression modification (Kovalchuk et al., 2005). Nevertheless, under lead stress condition certain amino acid like proline increases (Qureshi et al., 2007) a major role is played by such proteins in the tolerance of the plant biochemical and morphological differences (Kanwal et al., 2014). However, the extent of these effects differs and depends on the period of exposure, the heavy metal concentration, the developmental stage of plant and organ of interest (Pourrut et al., 2012).
Sunflower (Helianthus annuus L.) possess important agronomic traits, such as tolerance to high and low temperatures and adaptation to variety of climate and soil is among the common environmental plants that is used in diverse situation because of its ability to grow fast with high biomass and it can hyper accumulate heavy metals (Kamil, et al., 2019). Several methods are already abound in clean-up of the environment from heavy metals. Physicochemical processes are regarded labour intensive, expensive, destructive and sometimes are associated with some secondary problems (Wu et al., 2010). However, phytoremediation is cost effective, efficient, environmental and eco-friendly cleaning method with wide acceptance (Revathi et al., 2011). This involves the use of green plants to purify soils, sediments, air and water. There are different types of remediation process these include phytofiltration, phytoremediation, phytodegradation, phytoextraction, phytovolatalization and phytostabilization, depending on the mechanisms for the remediation (Kamil et al., 2019). Human activities such as mining and smelting of metals, electroplating, gas exhaust, fuel production, fertilizer, sewage and application of pesticides have made metal pollution one of the most severe environmental problems threatening plant growth and 
yield by inciting some inert element making them soluble and available for plant uptake, thereby hazardous to human (Prassad, 2007). Heavy metals (such as Lead, Cadmium, Chromium) have shown a negative effect particularly in non-tolerant species of plant as they affect the plant cellular activities such as photosynthesis, respiration, mineral nutrition, membrane structure and function and gene expression (Nasser et al., 2014). Though, some naturally occurring metals (such as $\mathrm{Fe}$ ) are not known to have toxic effects, those of anthropogenic source (such as Arsenic, Lead, Chromium, Cobalt and Cadmium) are not biodegradable and could cause various diseases and disorder even in relatively low concentration (Naseer et al., 2014). Methods used in remediating heavy metal contaminated soil in developed countries are from high technological industries and these methods require expertise and are usually expensive to practice. The productivity of contaminated soils requires proper management practices. This could be attained through the application of phytoremediation on heavy metal contaminated soils. Therefore, this work is aimed at assessing the $H$. annuus in remediating $\mathrm{Pb}$ and $\mathrm{Cr}$ polluted soils. The objective of the study is to evaluate the potentials of sunflower in phytoremediation of chromium and lead from contaminated soil and to examine the rate of accumulation in roots, stems and leaves of the plant.

\section{MATERIALS AND METHODS}

Description of the study site: The studies was conducted at the research site of faculty of Agriculture, Ibrahim Badamasi Babangida University, Lapai (IBBUL), Niger State. The study area is located on latitude $09^{\circ} 4^{\prime} 39^{\prime \prime} \mathrm{N}$ and longitude $06^{\circ} 34^{\prime} 27^{\prime \prime} \mathrm{E}$ in the Southern Guinea Savannah of Nigeria. Lapai is a local government area in Niger State, Nigeria; adjoined to Federal Capital Territory, it has an area of 3,051 km² and a population of 110,127 (NPC, 2006). The area experiences both dry and wet seasons. Annual rainfall ranges from about $1200 \mathrm{~mm}$ in the north to $1600 \mathrm{~mm}$ in the south and the duration varies from 150 to 210 days with mean maximum temperature of $32^{\circ} \mathrm{C}$ (Tsepav et al., 2014). The inhabitant are predominantly farmers, among the crops they cultivate are maize, guinea corn, millet, groundnut and soybean (Garba, et al., 2017).

Treatments and Experimental Design: The study was carried out in the research site of faculty of Agriculture, Ibrahim Badamasi Babangida University Lapai (IBBUL). The treatments consisted of 2 heavy metals which were Lead $\left(\mathrm{Pb}\left(\mathrm{NO}_{3}\right)_{2}=17.4 \mathrm{~g}\right)$ and Chromium $\left(\mathrm{Cr}_{2} \mathrm{O}_{3}=34.9 \mathrm{~g}\right)$ and a control. Seeds were grown in plastic pots filled with equal quantity of composite oil sample $(10 \mathrm{~kg})$, while plastic pots were inoculated with heavy metals based on the treatment combination. The experiment was laid out in Completely Randomized Design (CRD) replicated 3 times. Ten seeds were sown on each pot at equal distance and there were irrigated every 2-3 days for a period of eighty-four days.

Soil Sample and Analysis: Soil samples were randomly collected at depths of $0-15 \mathrm{~cm}$ from training and research farm of IBBU with the aid of an auger. Soil samples were bulked and 500g was weighed, air dried, crushed and sieved to pass through $2 \mathrm{~mm}$ sieve for determination of physical and chemical properties of the soil using standard procedure (Table 1). The remaining soil sample was used for filling the plastic pots for the plant growth.

Plant sample collection and analysis: Plant samples were collected at an interval of two weeks by uprooting without replacement using hand and separated into leaves, stems and roots. The samples were thoroughly washed off of soil particles and rinsed with distilled water and dried to a constant weight in an oven at a temperature of $70^{\circ} \mathrm{C}$. The dried samples were ground to powder using pestle and mortar and sieved using $2 \mathrm{~mm}$ mesh. Dried powdered samples were digested with $60 \% \mathrm{HClO}_{4}$, concentrated $\mathrm{HNO}_{3}$ and $\mathrm{H}_{2} \mathrm{SO}_{4}$ (Opaluwa et al., 2012). The digested samples were analyzed for Chromium (Cr) and Lead $(\mathrm{Pb})$ using atomic absorption spectrophotometer (AAS). The result of the data was subjected to analysis of variance (ANOVA) using SAS statistical package at $\mathrm{p} \leq 0.05$.

\section{RESULTS AND DISCUSSION}

Soil analysis: Soil analysis was conducted to ascertain the physical and chemical properties of the soil. Result showed that soil used for the experiment was texturally sandy loam, acidic at $\mathrm{pH} 5.4$, low in organic carbon $(2.53 \%)$, low total nitrogen $(0.79 \%)$ and moderately available phosphorus $\left(16.53 \mathrm{cmolkg}^{-1}\right)$. The exchangeable cations showed that sodium (1.10 cmolkg $\left.{ }^{-1}\right)$, potassium $\left(0.18 \mathrm{cmolkg}^{-1}\right)$, calcium $(4.11$ $\mathrm{cmolkg}^{-1}$ ) and magnesium $\left(5.26 \mathrm{cmolkg}^{-1}\right)$ were high, very low, low and high respectively (Table1).

The poor status of soil may have aroused from continuous cropping activities in field which must have caused degradation effects on the soil. These results corroborate the report of Tully et al. (2015) who revealed that the possible cause of soil degradation is expansion and intensification of agriculture in efforts to feed its growing population especially in Sub-Saharan Africa (SSA). 
Table 1: Physical and chemical characteristics of soil before

\begin{tabular}{|c|c|c|}
\hline \multicolumn{3}{|c|}{ sowing } \\
\hline Parameter & Values & Rating \\
\hline Soil $\mathrm{p}^{\mathrm{H}}$ & 5.4 & Acidic \\
\hline Organic carbon $(\%)$ & 2.53 & Very High \\
\hline Total nitrogen $(\%)$ & 0.19 & High \\
\hline Available phosphorus (\%) & 16.53 & Moderate \\
\hline $\mathrm{Na}\left(\mathrm{cmolkg}^{-1}\right)$ & 1.10 & High \\
\hline $\mathrm{K}\left(\mathrm{cmolkg}^{-1}\right)$ & 0.18 & High \\
\hline $\mathrm{Ca}\left(\mathrm{cmolkg}^{-1}\right)$ & 4.11 & Moderate \\
\hline $\mathrm{Mg}\left(\mathrm{cmolkg}^{-1}\right)$ & 5.26 & High \\
\hline Sand (\%) & 84.24 & - \\
\hline Silt (\%) & 10.28 & - \\
\hline Clay (\%) & 5.48 & - \\
\hline Soil Textural Class & Sandy Loam & - \\
\hline
\end{tabular}

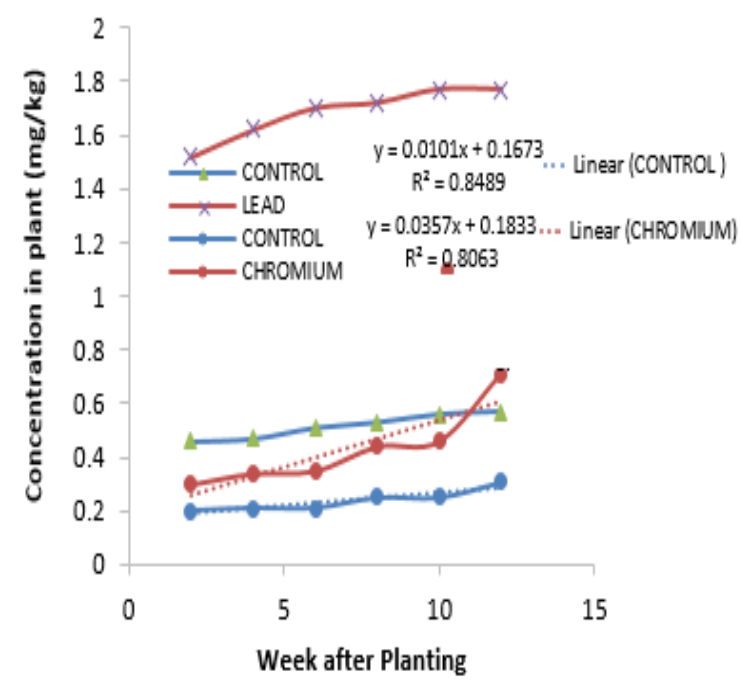

Fig 1: Lead and Chromium concentration in plant

Lead and chromium concentration in plant: Result from plant samples analyzed (figure 1), shows that both lead and chromium were below permissible limit in all the samples collected at 2, 4, 6, 8, 10 and 12 week after planting. Highest lead concentration was recorded in 10 and $12 \mathrm{WAP} 1.77$ and $1.77 \mathrm{mg} / \mathrm{kg}$ respectively (figure 1) compared to the control which recorded 0.56 and $0.57 \mathrm{mg} / \mathrm{kg}$ respectively the above result is in line with Saima et al., (2010) who noted that Helianthus annuus L., showed more uptake of $\mathrm{Pb}$ in comparison to other metals. Also the concentration of chromium (figure 2), was 0.46 and $0.71 \mathrm{mg} / \mathrm{kg}$ as against the control 0.25 and $0.31 \mathrm{mg} / \mathrm{kg}$ in the analyzed samples in 2 and 12 WAP.

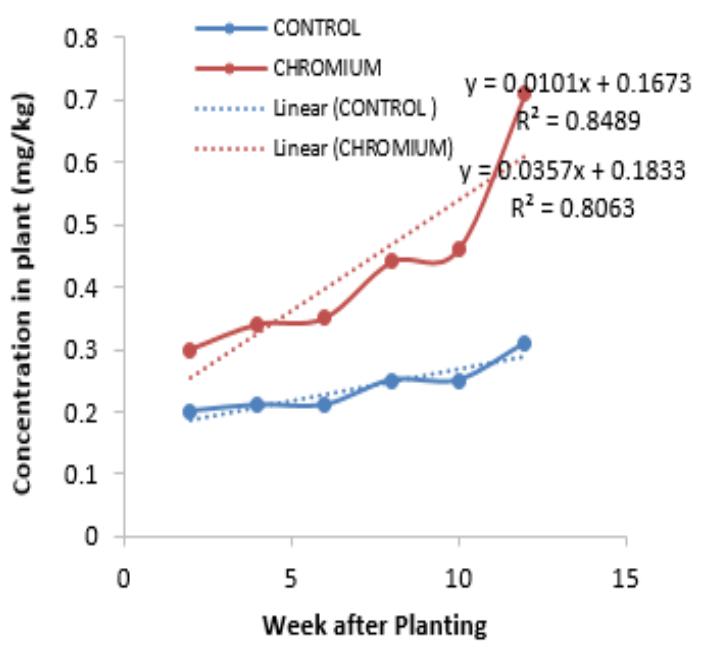

Fig 2: Chromium concentration in plant

Lead Accumulation in Plant Parts: In Table 2, Lead accumulation in the roots of sunflower was very high at $12 \mathrm{WAP}$ and low at $2 \mathrm{WAP}(2.04 \mathrm{mg} / \mathrm{kg}$ and 1.60 $\mathrm{mg} / \mathrm{kg}$ ). It was observed that during the growing period there was continuous accumulation of lead in root of the plants before it is translocated to other parts of the plant, this was observed in contaminated soils. Similarly, the stem recorded high value at $12 \mathrm{WAP}$ and low at 2 WAP (1.98 mg/kg and $1.53 \mathrm{mg} / \mathrm{kg}$ ). Furthermore, in the leaves, lead accumulates highest at $12 \mathrm{WAP}$ and the lowest at $2 \mathrm{WAP}(1.84 \mathrm{mg} / \mathrm{kg}$ and $1.12 \mathrm{mg} / \mathrm{kg}$ ) respectively. The values obtained in the roots, stems and leaves were all above the control but did not exceed the plant tolerant limit of $2.5 \mathrm{mg} / \mathrm{kg}$ as was reported by Francis, (2017).

Table 2: Lead accumulation in the plant parts $(\mathrm{mg} / \mathrm{kg})$. Results are mean of replicates \pm standard deviation

\begin{tabular}{llllllll}
\hline Treatment & Plant Part & 2 WAP & 4 WAP & 6 WAP & 8 WAP & 10 WAP & 12 WAP \\
\hline Control & Root & $1.27 \pm 0.30$ & $1.31 \pm 0.10$ & $1.38 \pm 0.20$ & $1.38 \pm 0.20$ & $1.72 \pm 0.10$ & $1.91 \pm 0.30$ \\
& Stem & $0.97 \pm 0.10$ & $1.00 \pm 0.00$ & $1.04 \pm 0.10$ & $1.07 \pm 0.30$ & $1.41 \pm 0.20$ & $1.45 \pm 0.10$ \\
& Leave & $0.31 \pm 0.10$ & $0.48 \pm 0.30$ & $0.48 \pm 0.20$ & $0.50 \pm 0.10$ & $1.33 \pm 0.10$ & $1.46 \pm 0.10$ \\
Lead & Root & $1.60 \pm 0.20$ & $1.68 \pm 0.30$ & $1.68 \pm 0.10$ & $1.69 \pm 0.10$ & $1.79 \pm 0.00$ & $2.04 \pm 0.30$ \\
& Stem & $1.53 \pm 0.20$ & $1.60 \pm 0.20$ & $1.63 \pm 0.10$ & $1.69 \pm 0.30$ & $1.78 \pm 0.10$ & $1.98 \pm 0.20$ \\
& Leave & $1.12 \pm 0.30$ & $1.42 \pm 0.10$ & $1.48 \pm 0.30$ & $1.60 \pm 0.20$ & $1.72 \pm 0.20$ & $1.84 \pm 0.10$ \\
\hline
\end{tabular}

Table 3: Chromium accumulation in the plant parts $(\mathrm{mg} / \mathrm{kg})$. Results are mean of replicates \pm standard deviation

\begin{tabular}{cccccccc}
\hline Treatment & Plant Part & 2 WAP & 4 WAP & 6 WAP & 8 WAP & 10 WAP & 12 WAP \\
\hline Control & Root & ND & $0.02 \pm 0.10$ & $0.04 \pm 0.20$ & $0.04 \pm 0.10$ & $0.06 \pm 0.10$ & $0.09 \pm 0.00$ \\
& Stem & ND & ND & $0.02 \pm 0.10$ & $0.02 \pm 0.10$ & $0.03 \pm 0.10$ & $0.03 \pm 0.00$ \\
& Leave & ND & ND & ND & ND & $0.01 \pm 0.10$ & $0.02 \pm 0.00$ \\
Chromium & Root & $0.16 \pm 0.20$ & $0.30 \pm 0.10$ & $0.30 \pm 0.10$ & $0.32 \pm 0.30$ & $0.40 \pm 0.20$ & $1.60 \pm 0.20$ \\
& Stem & $0.09 \pm 0.30$ & $0.16 \pm 0.10$ & $0.29 \pm 0.20$ & $0.31 \pm 0.10$ & $0.32 \pm 0.20$ & $0.39 \pm 0.00$ \\
& Leave & $0.09 \pm 0.10$ & $0.12 \pm 0.20$ & $0.15 \pm 0.10$ & $0.20 \pm 0.20$ & $0.21 \pm 0.10$ & $0.27 \pm 0.00$ \\
\hline
\end{tabular}


Chromium Accumulation in Plant Parts: Chromium concentration in roots, stem and leaves of plant were presented in Table 3. Chromium accumulation in contaminated soils kept increasing from 2 WAP to 12 WAP in both the roots, stems and leaves of the plants. Roots recorded $1.60 \mathrm{mg} / \mathrm{kg}$ and $0.16 \mathrm{mg} / \mathrm{kg}$ at 12 and 2 WAP. The stems recorded $0.39 \mathrm{mg} / \mathrm{kg}$ at $12 \mathrm{WAP}$ and $0.09 \mathrm{mg} / \mathrm{kg}$ at $2 \mathrm{WAP}$, so also the leaves recorded $0.27 \mathrm{mg} / \mathrm{kg}$ at $12 \mathrm{WAP}$ and $0.09 \mathrm{mg} / \mathrm{kg}$ at $2 \mathrm{WAP}$. This indicates that roots absorbed first and in large amount before translocated to other parts of the plants. The concentration of lead $\mathrm{Pb}$ in plant parts varied from 1.12 to $2.04 \mathrm{mg} / \mathrm{kg}$, compared to the permissible limit for plants recommended by (WHO, 1996) $(2 \mathrm{mg} / \mathrm{kg})$, were below permissible limit except the root at 12 WAP where $2.04 \mathrm{mg} / \mathrm{kg}$ was recorded which is slightly above the limit (Table 2). The value of chromium $(\mathrm{Cr})$ in the plant parts varied from not detected (ND) to 1.60 $\mathrm{mg} / \mathrm{kg}$, compared to the permissible limit for plants recommended by (WHO, 1996) $(1.30 \mathrm{mg} / \mathrm{kg}) \mathrm{Cr}$. All the plant parts are below the standard except the root at $12 \mathrm{WAP}$ which recorded $1.60 \mathrm{mg} / \mathrm{kg}$ (Table 3). This is as a result of slow uptake of $\mathrm{Cr}$ by plant shoot Ogundele et al., (2015). Finally, the concentrations of both lead and chromium in the three parts of treated plants were found to be in the order: leaves $<$ stem<roots which was also reported by Kamil et al., (2019).

Conclusion: Phytoremediation is a good approach for remedying soils contaminated with heavy metals from oil spillage, industrial sludge and effluent from hospitals. This study made an attempt in evaluating the potentials of sunflower (Helianthus annuus L.) in phytoremediation of chromium and lead from contaminated soil. Conclusively, (Helianthus annuus L.) was found to absorb lead and chromium without much expression of stress condition throughout the growing period. Therefore, sunflower (Helianthus annuus L.) is suitable for use in the phytoremediation of contaminated soils.

\section{REFERENCE}

Adejube, AAH; Anteyi, A; Garba, FH; Oyekunle, OA; Kudaisi, FO (2017). Bioremediating activity of sunflower (Helianthus annuиs L.) on contaminated soil from challawa industrial area, Kano-State Nigeria. Int'l J. Agric. Earth Sci. 3(5): 1-11

Atta, MI; Gulshan, AB; Ahmad, N; Saeed, S (2014). Toxicological study of heavy metals on early growth response of sunflower (Helianthus annuus L.). ARPN J. Agric Biol Sci. 9(2): 46-50
Esu, IE (1991). Detail soil survey of NIHORT farm at Bunkure, Kano State, Nigeria. Institute for Agricultural Research, Samaru, Zaria-Nigeria.

Francis, E (2017). Phytoremediation potentials of sunflower (Helianthus annuus L.) Asteraceae on contaminated soils of abandoned dumpsites. Int' $l$ J. Sci. Eng. Res. 8 (1): 1751-1757

Garba, Y; Ahmed, B; Katung, MD; Lawal, AF; Abubakar, HL (2017). Profitability of Striga tolerant Maize Variety (SAMAZ 17) amongst smallholder farmers in Lapai, Niger State, Nigeria. S. Afr. J. Agric. Ext. 45(1): 1-9

Kamil, M; Jabori, AL; Athar, KK (2019). Evaluation of sunflower (Helianthus annuus L) phytoremediation of Lead contaminated soil, $J$. Pharm. Sci. Res. 11 (3): 947-854

Kanwal, P; Gupta, S; Arora, S; Kumar, A (2014). Identification of genes involved in carbon metabolism from Eleusine Coracan (L.) for understanding their light-mediated entrainment and regulation. Plant cell rep 33

Kuvalchuk, I; Titov, V; Hohn, B; Kovalchuk, O (2005). Transcriptone profiling reveals similarities and differences in plant responses to cadmium and lead. Mutat. Res. Fundam Mol. Mech. Mutagen. 570(2): 149-161

Lucia, HGC; Maria, AE; Rama, SS (2011). Effect on plant growth and heavy metal accumulation by sunflower. J. Phytol. 3(2): 4-9

National Population Commission (2006). Federal Republic of Nigeria, Population and Housing Census (NPC, 2006)

Naseer, S; Soad, E; El-Shintinawy, F (2014). Phytoremediation of Lead and Cadmium Contaminated Soil Using Sunflower Plant. J. Stress Physiol. Biochem. 10(1): 122-134.

Ogundele, DT; Adio, AA; Oludele, EO (2015). Heavy metal concentration in plant and soil along heavy traffic roads in North Central Nigeria. J. Environ Analy Toxicol. 5(6): 334

Opaluwa, OD; Aremu, MO; Ogbo LO; Abiola, KA; Odiba, IE; Abubakar, MM; Nweze, NO (2012). Heavy Metal concentration in soils, plant leaves and Crops grown around dumpsites in Lafia Metropolis, Nasarawa State, Nigeria. Pelagia Research Library, Advances in Applied Science Research 3(2): 780-784 
Prassad, MNV (2007). Sunflower (Helianthus annuus L.) A Potential Crop for Environmental Industry. HELIA, 30(46): 167-174.

Pourrut, B; Shahid, M; Dumat, C; Winterton, C; Pinelli, E (2012). Lead uptake, toxicity, and detoxification in plants. Reviews of Environmental Contamination and Toxicology. 213: 113-136

Qureshi, M; Abdin, M; Qadir, S; Iqbal, M (2007). Lead-induced oxidative stress and metabolic alterations in cassia angustifolia Vahl. Biol. Plantarum 51(1):121-128

Remillard, A (2014). US Fish and Wild Life Service Issue. FINAL Rule Protecting Tree Flower. Endangered Species Law and Policy, Nossaman CLP.

Revathi, K; Harbabu, TE; Sudha, PN (2011). Phytoremediation of Chromium contaminated soil using sorghum plants. Int'l J. Environ. Sci. 2(2): 413-428

Saima, M; Haq, NB; Muhammad, K; Anwarulhaq, M; Sher, MS (2010). Potentials of sunflower (Helianthus annuus L.) for phytoremediation of Nickel $(\mathrm{Ni})$ and Lead $(\mathrm{Pb})$ contaminated water. Pakis. J. Bot. 42(6): 4017-4026
Tsepav, MT; Bello, A; Gbedako AA (2014). Geoelectric Investigation of some part of Ibrahim Badamasi Babangida University, Lapai, Nigeria. Phy. Sci. Int'l J. 4(4): 623-635

Tully, K; Sullivan, C; Weil, R; Sanchez, P (2015). The State of Soil Degradation in Sub- Saharan Africa: Baselines, Trajectories, and Solutions. Sustainability. 7. 6523-6552

WHO, (1996). Permissible limits of heavy metals in soil and plants (Geneva: World Health Organization) Switzerland.

Winska-Krysiak, M; Koropacka, K; Gawronski, S (2015). Determination of the tolerance of sunflower to lead-induced stress. J. Element. 20 (2): 491-502.

Wu, G; Kang, H; Zhang, X; Shao, H; Chu, L; Ruan, C (2010). A critical review on the bio-removal of hazardous heavy metals from contaminated soils: issues progress, eco-environmental concerns and opportunities. J. Hazard. Mater. 174: 1-8 